\title{
Study of specimen stability for biochemical parameters
}

\author{
Kirankumar P. Chauhan ${ }^{1}$, Jatin D. Patel ${ }^{2, *}$, Sonali Prajapati ${ }^{3}$, Amit Trivedi $^{4}$ \\ ${ }^{\mathbf{1}}$ Associate Professor, ${ }^{\mathbf{2}}$ Assistant Professor, Dept. of Biochemistry, GMERS Medical College, Gandhinagar, \\ Gujarat, ${ }^{3}$ Student, ${ }^{4}$ Asistant Professor, Dept. of Biochemistry, Pramukhswami Medical College, Shree Krishna \\ Hospital, Karamsad, Anand, Gujarat, India \\ *Corresponding Author: \\ Email: drjatinpatel209@gmail.com
}

\begin{abstract}
Introduction: The blood sample is collected and transported to the laboratory for analysis, during this time the samples bares many extra-analytical factors prior to analysis. Contact time of plasma or serum with the blood cells is one of these factors because of ongoing cell metabolism as well as active and passive movement of analytes in cellular compartments.

Aim and Objective: The aim of our study is to determine the stability of different seventeen biochemical parameters in primary collection (without separation of serum/plasma) and Secondary collection (with separation of serum/plasma) tube.

Materials and Methods: Hundred patients' venous blood sample were collected in plain vacutainer and fluoride vacutainer (primary tube), set of the seventeen biochemical analytes like sodium, potassium, ionized calcium, chloride, glucose, creatinine, urea, uric acid, alkaline phosphatase, alanine aminotransferase, aspartate aminotransferase, total protein, albumin, bilirubin, triglyceride, total cholesterol and HDL-cholesterol tests were analysed. Once the tests were carried out from primary tube, approximately half serum was separated into two aliquots (secondary collection tube). All tubes were stored at 2 to $8^{\circ} \mathrm{C}$. After $24 \mathrm{hr}$ and $48 \mathrm{hr}$ again same sate of tests were performed on the same equipment. Statistical analysis was done after that.

Results: Out of seventeen analytes most analytes remained stable in both primary and secondary tubes up to $48 \mathrm{hr}$ at 2 to $8^{\circ} \mathrm{C}$, these includes chloride, creatinine, urea, uric acid, total bilirubin, total protein, albumin. alkaline phosphatase (ALP), aspartate aminotransferase (AST) and alanine aminotransferase (ALT). Plasma glucose decreased in both primary and secondary collection tube but concentration is within significant change limit (SCL). While serum potassium is increase $28.84 \%$ at $24 \mathrm{hr}$ and $75.58 \%$ at $48 \mathrm{hr}$; concentration is also out of SCL range in primary collection tube even though samples stored at $2-8^{0} \mathrm{C}$.

Conclusion: Most biochemical analytes will remain stable for $48 \mathrm{hr}$ at $2-8^{0} \mathrm{C}$, only few analytes like plasma glucose and serum potassium requires stringent control before serum-clot separation.
\end{abstract}

Keywords: Collection tube, Pre-analytical factors, Specimen stability.

Received: $23^{\text {rd }}$ September, 2017

Accepted: 04 ${ }^{\text {th }}$ December, 2017

\section{Introduction}

Clinical laboratory tests are used by clinicians for diagnosis, monitoring and to check the prognosis in patients with different diseases. A number of factors, primarily pre-analytical, analytical and/or normal biological variations affect the accuracy of test results. Pre-analytical factors such as blood sample collection and handling, diet, exercise and drug intake can affect the test result. Test results can be biased by prolonged contact of plasma or serum with cells, because of ongoing metabolism as well as active and passive movement of analytes between the plasma or serum and cellular compartments. The key characteristics of the test are its bias and imprecision. Bias is primarily an analytical characteristic, in which reported results differ from the actual value. Imprecision is due to both physiological and analytical factors. ${ }^{1}$ Bias and imprecision are well understood by manufacturers and laboratory scientists. There are internationally accepted protocols for establishment of their claims and performance verification is done routinely in clinical laboratories.

Stability, in contrast, has greater variability in meaning for both manufacturers and users. This is in large part because stability is not a directly measured characteristic but rather is understood as the capability for a product to retain its stated composition, properties and performance.

Generally, the laboratory receives the specimen in the form of whole blood, from which the serum is separated by centrifugation. For reliable as well as clinically useful test results, the time interval between blood collection and serum separation must be controlled. Ideally, the serum should be separated as soon as possible after clot formation is complete (usually $30 \mathrm{~min}$ ) to avoid clot- 
induced changes in the concentration of serum analytes. However, in practice very few routine specimens can be processed within this time interval as collection of blood samples from one laboratories or collection centre and analyze it in another centre has become latest trendy in current years to decrease cost per test. Therefore, the extra-analytical factors affecting the test result such as prolonged storage of sample at high or low temperature, inappropriate handling (without frozen packs) are still area of interest. ${ }^{2,3}$ Although it is recommended to analyze freshly drawn serum or plasma for test, but delay in testing process or reuse of the samples for missing results may cause false test result are sometime inevitable. ${ }^{4-6}$

In the Chu and MacLeod study of 26 analytes, the effects of a 72-hour contact time at room temperature were determined. Many of the analytes stable for 48-hour and retained stability for an additional 24 hours. Analytes adversely affected by 72-hour contact include: glucose (decreased); potassium (increased); phosphorus (increased); creatinine (increased); folate (decreased); and vitamin $\mathrm{B}_{12}$ (increased). Minimally affected analytes include: Lactate Dehydrogenase (increased); chloride (decreased); calcium (decreased); ferritin (increased); and sodium (increased). ${ }^{7}$

A study by Rehak and Chiang conducted to determine stabilities of lipase, Thyroid Binding globulin $\mathrm{G}$ and TSH in unseparated serum for 24 hours at seven different temperatures $\left(3^{\circ} \mathrm{C}, 10^{\circ} \mathrm{C}\right.$, $15^{\circ} \mathrm{C}, 22^{\circ} \mathrm{C}, 25^{\circ} \mathrm{C}, 30^{\circ} \mathrm{C}$ and $38^{\circ} \mathrm{C}$ ). Generally, 22 to $25^{\circ} \mathrm{C}$ is considered as room temperature and at $22^{\circ} \mathrm{C}$, changes were observed for glucose (decreased), potassium (increased), phosphorus(increased), Alanine aminotransferase(increased), Aspartate aminotransferase (increased) and creatinine(increased). Higher the temperature, the more accentuated the alteration. ${ }^{8}$ Another time-temperature study $\left(\right.$ at $0^{\circ} \mathrm{C}, 23^{\circ} \mathrm{C}$ and $30^{\circ} \mathrm{C}$ ) substantiates the instability of many analytes at temperatures above room temperature $\left(30^{\circ} \mathrm{C}\right)$ : glucose (decreased by four hours); phosphorus (increased by six hours); Alanine aminotransferase and Aspartate aminotransferase (increased by eight hours); and potassium (increased by 24 hours). ${ }^{9}$ Study by Oliver TK et al expected Potassium was significantly increased at temperatures below $15^{\circ} \mathrm{C} .{ }^{10}$ In a study of selected analytes, ionized calcium in unseparated serum was stable for only two hours at $25^{\circ} \mathrm{C}$, but stable for up to 96 hours at $4{ }^{\circ} \mathrm{C} .{ }^{11}$

In Zhang and fellow investigators ${ }^{12}$ evaluated the stabilities of 63 analytes, serum in contact with cells for 24 hours. They determined that serum should be separated from the clot within three hours for glucose, potassium and phosphorus, and within six hours for albumin, bicarbonate, chloride, C-peptide, HDLcholesterol, iron, LDL-cholesterol and total protein. All other analytes in their study were stable for 24 hours without serum separated from the clot.

It is recommended that serum or plasma be physically separated from contact with cells as soon as possible with a maximum time limit of two hours from the time of collection, unless conclusive evidence indicates that longer contact times do not contribute to error of the results. However, it is not done routinely in most of the laboratories and also difficult to separate out serum or plasma from contact with cells within 2 hours, also it is mandatory to make evidence to do ad-on test or re-testing from stored sample with acceptable variation in test result. Therefore, it is felt significant to do a systematic study of in-house specimen stability.

\section{Material and Methods}

This cross-sectional study was conducted at Shree Krishna Hospital, Pramukhswami Medical College, Karamsad from Jun to December 2013. We have selected 100 blood samples randomly from the rack once the analysis of the sample for the requested tests is over at clinical biochemistry laboratory of said institute during study period. Once the requested test is carried out the specimen is divided into two tubes, first is primary collection tube (without separation of serum from clot) and another in secondary collection tube (with separated serum from cell contact). Both these sample tubes were stored at 2 to $8^{\circ} \mathrm{C}$ in refrigerator. Direct exposure to sunlight is avoided for stored specimens. sodium, potassium, ionized calcium, chloride, glucose, creatinine, urea, uric acid, total protein, albumin, total bilirubin, total cholesterol, triglyceride, HDL-cholesterol alkaline phosphatase, alanine aminotransferase and aspartate aminotransferase tests were performed from the specimen stored at 2 to $8^{\circ} \mathrm{C}$ after 24 hours \& 48 hours. Refrigerated sample were analyzed once it attains the room temperature. We have analyzed all this parameters in Cobas Integra 400 plus fully automated biochemistry analyzer. Standard reagent kits from Cobas were used for analysis of sample.

This study will utilize specimen (Patient's serum) once the requested test is done. The study result will not be intimated to patient or doctor for patient management. For that reason, HRA 
committee has waved off requirement of patient's consent for this study.

Inclusion criteria:

1. Samples were randomly selected from samples received for analysis in biochemistry laboratory.

\section{Exclusion criteria:}

1. Hemolysed sample are excluded as hemolysis may interfere with result.

2. Sample inadequate to perform all mentioned seventeen parameters.

\section{Statically Analysis}

To establish time dependent changes in each analyte, in plasma and serum with and without prolonged contact with cells the mean of all 100 specimen all analytes were obtained for $0.5 \mathrm{hr}$, $24 \mathrm{hr}$ and $48 \mathrm{hr}$ time interval. Statistical analysis of result was done by Students' t-test. In this analysis, variable showing P- value 0.05 or less were considered to be statistically significant.

\section{Result}

Table 1: Mean (Standard Error)

\begin{tabular}{|c|c|c|c|c|c|c|c|c|}
\hline \multirow[t]{2}{*}{ Analytes } & \multirow[b]{2}{*}{ 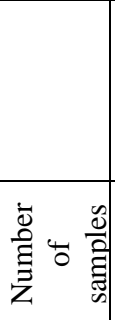 } & \multirow[b]{2}{*}{ 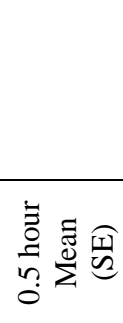 } & \multicolumn{2}{|c|}{$\begin{array}{c}\text { Primary collection } \\
\text { (without } \\
\text { separation of } \\
\text { serum/plasma) } \\
\text { tube } \\
\end{array}$} & \multicolumn{2}{|c|}{$\begin{array}{c}\text { Secondary } \\
\text { collection (with } \\
\text { separation of } \\
\text { serum/plasma) tube }\end{array}$} & \multirow[b]{2}{*}{ คे } & \multirow[b]{2}{*}{ U } \\
\hline & & & 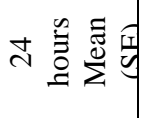 & 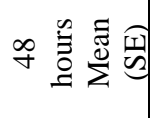 & 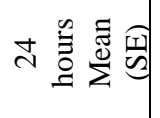 & 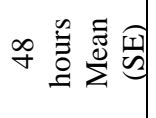 & & \\
\hline Sodium & 100 & $\begin{array}{l}137.11 \\
(0.30) \\
\end{array}$ & $\begin{array}{l}136.97 \\
(0.315) \\
\end{array}$ & $\begin{array}{l}135.82 \\
(0.323) \\
\end{array}$ & $\begin{array}{l}139.07 \\
(0.338)\end{array}$ & $\begin{array}{l}139.93 \\
(0.367)\end{array}$ & 1.37 & $133.3-140.9$ \\
\hline Potassium & 100 & $\begin{array}{c}4.497 \\
(0.059) \\
\end{array}$ & $\begin{array}{c}5.794 \\
(0.086) \\
\end{array}$ & $\begin{array}{l}7.896 \\
(0.16) \\
\end{array}$ & $\begin{array}{c}4.62 \\
(0.059) \\
\end{array}$ & $\begin{array}{c}4.71 \\
(0.063) \\
\end{array}$ & 0.08 & $4.3-4.8$ \\
\hline $\begin{array}{l}\text { Ionized } \\
\text { Calcium }\end{array}$ & 100 & $\begin{array}{c}1.25 \\
(0.006)\end{array}$ & $\begin{array}{c}1.19 \\
(0.007)\end{array}$ & $\begin{array}{c}1.18 \\
(0.007) \\
\end{array}$ & $\begin{array}{c}1.08 \\
(0.007)\end{array}$ & $\begin{array}{c}1.07 \\
(0.008)\end{array}$ & 0.03 & $1.17-1.33$ \\
\hline Chloride & 100 & $\begin{array}{l}104.3 \\
(0.38) \\
\end{array}$ & $\begin{array}{l}103.3 \\
(0.38) \\
\end{array}$ & $\begin{array}{l}102.8 \\
(0.37) \\
\end{array}$ & $\begin{array}{l}104.7 \\
(0.38) \\
\end{array}$ & $\begin{array}{l}105.3 \\
(0.40) \\
\end{array}$ & 2.40 & $97.6-111.0$ \\
\hline Glucose & 100 & $\begin{array}{l}164.8 \\
(8.42) \\
\end{array}$ & $\begin{array}{l}160.0 \\
(8.37)\end{array}$ & $\begin{array}{l}158.0 \\
(8.3) \\
\end{array}$ & $\begin{array}{l}162.2 \\
(8.67) \\
\end{array}$ & $\begin{array}{l}161.7 \\
(8.38)\end{array}$ & 2.88 & $156.7-172.9$ \\
\hline Creatinine & 100 & $\begin{array}{c}0.68 \\
(0.024) \\
\end{array}$ & $\begin{array}{c}0.68 \\
(0.026) \\
\end{array}$ & $\begin{array}{c}0.69 \\
(0.025) \\
\end{array}$ & $\begin{array}{c}0.69 \\
(0.025) \\
\end{array}$ & $\begin{array}{c}0.68 \\
(0.026) \\
\end{array}$ & 0.02 & $0.62-0.74$ \\
\hline Urea & 100 & $\begin{array}{l}21.7 \\
(0.97)\end{array}$ & $\begin{array}{c}22.2 \\
(0.95)\end{array}$ & $\begin{array}{l}22.3 \\
(0.95)\end{array}$ & $\begin{array}{c}21.7 \\
(0.96)\end{array}$ & $\begin{array}{l}21.8 \\
(0.95)\end{array}$ & 0.60 & $20.0-23.4$ \\
\hline Uric acid & 100 & $\begin{array}{c}5.37 \\
(0.13) \\
\end{array}$ & $\begin{array}{c}5.38 \\
(0.13) \\
\end{array}$ & $\begin{array}{c}5.40 \\
(0.13) \\
\end{array}$ & $\begin{array}{c}5.45 \\
(0.13) \\
\end{array}$ & $\begin{array}{c}5.49 \\
(0.13) \\
\end{array}$ & 0.07 & $5.17-5.57$ \\
\hline $\begin{array}{l}\text { Total } \\
\text { Protein } \\
\end{array}$ & 100 & $\begin{array}{c}6.9 \\
(0.045) \\
\end{array}$ & $\begin{array}{c}7.0 \\
(0.042) \\
\end{array}$ & $\begin{array}{c}7.0 \\
(0.044) \\
\end{array}$ & $\begin{array}{c}6.97 \\
(0.045) \\
\end{array}$ & $\begin{array}{c}7.0 \\
(0.05) \\
\end{array}$ & 0.16 & $6.45-7.35$ \\
\hline Albumin & 100 & $\begin{array}{c}4.41 \\
(0.043) \\
\end{array}$ & $\begin{array}{c}4.44 \\
(0.044)\end{array}$ & $\begin{array}{c}4.44 \\
(0.042)\end{array}$ & $\begin{array}{c}4.42 \\
(0.042)\end{array}$ & $\begin{array}{c}4.43 \\
(0.042) \\
\end{array}$ & 0.08 & $4.19-4.63$ \\
\hline $\begin{array}{l}\text { Total } \\
\text { Bilirubin } \\
\end{array}$ & 100 & $\begin{array}{c}0.57 \\
(0.35) \\
\end{array}$ & $\begin{array}{c}0.56 \\
(0.33) \\
\end{array}$ & $\begin{array}{c}0.55 \\
(0.33) \\
\end{array}$ & $\begin{array}{c}0.56 \\
(0.33) \\
\end{array}$ & $\begin{array}{c}0.57 \\
(0.33) \\
\end{array}$ & 0.02 & $0.51-0.63$ \\
\hline $\begin{array}{l}\text { Total } \\
\text { Cholesterol } \\
\end{array}$ & 100 & $\begin{array}{l}180.3 \\
(4.63) \\
\end{array}$ & $\begin{array}{l}182.3 \\
(4.67) \\
\end{array}$ & $\begin{array}{l}182.5 \\
(4.66) \\
\end{array}$ & $\begin{array}{l}181.7 \\
(4.69) \\
\end{array}$ & $\begin{array}{l}182.5 \\
(4.62) \\
\end{array}$ & 3.89 & $169.4-191.2$ \\
\hline $\begin{array}{l}\text { Triglycerid } \\
\text { e }\end{array}$ & 100 & $\begin{array}{c}124.2 \\
(5.7)\end{array}$ & $\begin{array}{c}127.4 \\
(5.7)\end{array}$ & $\begin{array}{c}128.5 \\
(5.7) \\
\end{array}$ & $\begin{array}{c}127.8 \\
(5.7) \\
\end{array}$ & $\begin{array}{l}129.6 \\
(5.7) \\
\end{array}$ & 2.43 & $117.4-131.0$ \\
\hline HDL-c & 100 & $\begin{array}{l}47.5 \\
(1.5) \\
\end{array}$ & $\begin{array}{l}46.9 \\
(1.4) \\
\end{array}$ & $\begin{array}{c}46.0 \\
(1.44) \\
\end{array}$ & $\begin{array}{c}45.9 \\
(1.43) \\
\end{array}$ & $\begin{array}{c}46.5 \\
(1.49) \\
\end{array}$ & 1.71 & $42.7-52.3$ \\
\hline ALT & 100 & $\begin{array}{c}21.2 \\
(1.38)\end{array}$ & $\begin{array}{l}21.35 \\
(1.36)\end{array}$ & $\begin{array}{l}21.34 \\
(1.36)\end{array}$ & $\begin{array}{c}21.3 \\
(1.35) \\
\end{array}$ & $\begin{array}{c}20.9 \\
(1.30)\end{array}$ & 0.59 & $19.6-22.9$ \\
\hline AST & 100 & $\begin{array}{l}22.98 \\
(1.27) \\
\end{array}$ & $\begin{array}{c}23.9 \\
(1.30) \\
\end{array}$ & $24(1.30)$ & $\begin{array}{l}23.86 \\
(1.31) \\
\end{array}$ & $\begin{array}{l}23.83 \\
(1.32) \\
\end{array}$ & 0.39 & $21.89-24.07$ \\
\hline ALP & 100 & $\begin{array}{l}78.27 \\
(3.36) \\
\end{array}$ & $\begin{array}{l}79.05 \\
(3.39) \\
\end{array}$ & $\begin{array}{l}79.21 \\
(3.36) \\
\end{array}$ & $\begin{array}{c}79.3 \\
(3.35) \\
\end{array}$ & $\begin{array}{l}80.21 \\
(3.40) \\
\end{array}$ & 2.90 & $70.15-86.39$ \\
\hline
\end{tabular}

USD $=$ Usual Standard Deviation SCL $=$ Significant Change Limit 
Table 2: Percent difference and $P$ value

\begin{tabular}{|c|c|c|c|c|}
\hline \multirow[t]{2}{*}{ Analytes } & \multicolumn{2}{|c|}{$\begin{array}{c}\text { Primary collection } \\
\text { (without separation of serum/plasma) } \\
\text { tube }\end{array}$} & \multicolumn{2}{|c|}{$\begin{array}{c}\text { Secondary collection } \\
\text { (with separation of serum/plasma) tube }\end{array}$} \\
\hline & $\begin{array}{l}24 \text { hours } \\
\% \text { diff } \\
\text { (P value) }\end{array}$ & $\begin{array}{l}48 \text { hours } \\
\% \text { diff } \\
\text { (P value) }\end{array}$ & $\begin{array}{l}24 \text { hours } \\
\% \text { diff } \\
\text { (P value) }\end{array}$ & $\begin{array}{l}48 \text { hours } \\
\% \text { diff } \\
\text { (P value) }\end{array}$ \\
\hline Sodium & $\begin{array}{l}-0.10 \\
(0.34)\end{array}$ & $\begin{array}{l}-0.94 \\
(0.00)\end{array}$ & $\begin{array}{c}1.43 \\
(0.00)\end{array}$ & $\begin{array}{c}2.06 \\
(0.00)\end{array}$ \\
\hline Potassium & $\begin{array}{l}28.84 \\
(0.00)\end{array}$ & $\begin{array}{l}75.58 \\
(0.00)\end{array}$ & $\begin{array}{c}2.74 \\
(0.00)\end{array}$ & $\begin{array}{c}4.74 \\
(0.00)\end{array}$ \\
\hline Ionized Calcium & $\begin{array}{l}-4.80 \\
(0.00) \\
\end{array}$ & $\begin{array}{l}-5.60 \\
(0.00) \\
\end{array}$ & $\begin{array}{c}-13.60 \\
(0.00) \\
\end{array}$ & $\begin{array}{c}-14.40 \\
(0.00)\end{array}$ \\
\hline Chloride & $\begin{array}{l}-0.96 \\
(0.00)\end{array}$ & $\begin{array}{l}-1.44 \\
(0.00)\end{array}$ & $\begin{array}{c}0.38 \\
(0.03)\end{array}$ & $\begin{array}{c}0.96 \\
(0.00)\end{array}$ \\
\hline Glucose & $\begin{array}{l}-2.91 \\
(0.00) \\
\end{array}$ & $\begin{array}{l}-4.13 \\
(0.00) \\
\end{array}$ & $\begin{array}{l}-1.58 \\
(0.02) \\
\end{array}$ & $\begin{array}{l}-1.88 \\
(0.00) \\
\end{array}$ \\
\hline Creatinine & $\begin{array}{l}0.00 \\
(1.0) \\
\end{array}$ & $\begin{array}{c}1.47 \\
(0.03) \\
\end{array}$ & $\begin{array}{c}1.47 \\
(0.13) \\
\end{array}$ & $\begin{array}{c}0.00 \\
(0.03) \\
\end{array}$ \\
\hline Urea & $\begin{array}{c}2.30 \\
(0.00) \\
\end{array}$ & $\begin{array}{c}2.76 \\
(0.00) \\
\end{array}$ & $\begin{array}{c}0.00 \\
(0.87) \\
\end{array}$ & $\begin{array}{c}0.46 \\
(0.43) \\
\end{array}$ \\
\hline Uric acid & $\begin{array}{c}0.19 \\
(0.25) \\
\end{array}$ & $\begin{array}{c}0.56 \\
(0.00) \\
\end{array}$ & $\begin{array}{c}1.49 \\
(0.00) \\
\end{array}$ & $\begin{array}{c}2.23 \\
(0.00) \\
\end{array}$ \\
\hline Total Protein & $\begin{array}{c}1.45 \\
(0.00) \\
\end{array}$ & $\begin{array}{c}1.45 \\
(0.00) \\
\end{array}$ & $\begin{array}{c}1.01 \\
(0.00) \\
\end{array}$ & $\begin{array}{c}1.45 \\
(0.00) \\
\end{array}$ \\
\hline Albumin & $\begin{array}{c}0.68 \\
(0.00) \\
\end{array}$ & $\begin{array}{c}0.68 \\
(0.00) \\
\end{array}$ & $\begin{array}{c}0.23 \\
(0.75) \\
\end{array}$ & $\begin{array}{c}0.45 \\
(0.15) \\
\end{array}$ \\
\hline Total Bilirubin & $\begin{array}{l}-1.75 \\
(0.10) \\
\end{array}$ & $\begin{array}{l}-3.51 \\
(0.02) \\
\end{array}$ & $\begin{array}{l}-1.75 \\
(0.07) \\
\end{array}$ & $\begin{array}{c}0.00 \\
(0.05) \\
\end{array}$ \\
\hline Total Cholesterol & $\begin{array}{c}1.11 \\
(0.00) \\
\end{array}$ & $\begin{array}{c}1.22 \\
(0.00) \\
\end{array}$ & $\begin{array}{c}0.78 \\
(0.00)\end{array}$ & $\begin{array}{c}1.22 \\
(0.00)\end{array}$ \\
\hline Triglyceride & $\begin{array}{c}2.58 \\
(0.00) \\
\end{array}$ & $\begin{array}{c}3.46 \\
(0.00) \\
\end{array}$ & $\begin{array}{c}2.90 \\
(0.00) \\
\end{array}$ & $\begin{array}{c}4.35 \\
(0.00) \\
\end{array}$ \\
\hline HDL-c & $\begin{array}{l}-1.26 \\
(0.00)\end{array}$ & $\begin{array}{l}-3.16 \\
(0.00)\end{array}$ & $\begin{array}{l}-3.37 \\
(0.00)\end{array}$ & $\begin{array}{l}-2.11 \\
(0.00)\end{array}$ \\
\hline ALT & $\begin{array}{c}0.71 \\
(0.20) \\
\end{array}$ & $\begin{array}{c}0.66 \\
(0.27) \\
\end{array}$ & $\begin{array}{c}0.47 \\
(0.40) \\
\end{array}$ & $\begin{array}{l}-1.42 \\
(0.21) \\
\end{array}$ \\
\hline AST & $\begin{array}{c}4.87 \\
(0.00) \\
\end{array}$ & $\begin{array}{c}5.57 \\
(0.00) \\
\end{array}$ & $\begin{array}{c}3.83 \\
(0.00) \\
\end{array}$ & $\begin{array}{c}3.70 \\
(0.00) \\
\end{array}$ \\
\hline ALP & $\begin{array}{c}1.00 \\
(0.01) \\
\end{array}$ & $\begin{array}{c}1.20 \\
(0.00)\end{array}$ & $\begin{array}{c}1.32 \\
(0.00)\end{array}$ & $\begin{array}{c}2.48 \\
(0.00)\end{array}$ \\
\hline
\end{tabular}

The mean value, standard error, usual standard deviation and significant change limit are shown in table 1 . All analytes 0.5 hours mean values are within analytes reference interval. All analytes values for primary and secondary tube at 24 and 48 hours are within significant change limit except potassium and ionized calcium. From mean values at different time point shows upward trend in serum Total Cholesterol and Triglyceride and downward trend in HDLCholesterol and plasma Glucose.

Table 2 shows relative percent bias and $\mathrm{p}$ value. Positive \% bias is maximum in potassium in primary tube after 48 hours also evident in Graph No. 01. Similarly, maximum negative \% bias is maximum in serum ionized Calcium followed by plasma Glucose in primary tube after 48 hours also evident in Graph No.02. But major difference in serum potassium and plasma glucose is due to storage temperature; sample were stored at 2 to $8^{\circ} \mathrm{C}$ so hemolysis increases which results in increase in potassium on other hand glucose utilization decreases, because of this maximum decrease in glucose were $4.13 \%$ only.

Effect of time of storage of primary and secondary tube on test results were determined by two tailed paired sample Student's t test $(\mathrm{p}=$ 0.05 ), revealed significant difference in mean values of all analytes between 0.5 hours and 24 hours as well as 0.5 hours and 48 hours values, with or without serum-clot separation except for urea analyte.

\section{Discussion}

Being a tertiary care center and an academic institute, it is quite often that our clinical 
biochemistry department receive add-on test request, re-do test request when results and clinical findings are not correlate or rarely it happen that test has to perform from sample which were misplaced and found later on. In all such scenario question of sample stability and result reliability arise. Also the adverse effect on laboratory results of prolonged contact between cells and serum has long been recognized, and immediate separation of serum from cells has always been considered essential to accurate laboratory test results. The current recommendation of an acceptable time interval between blood drawing and serum separation is 2 hours. ${ }^{13}$ This guideline is also recommended by NABL (National Accreditation Board for Testing and Calibration Laboratories). However, it's observed that many Indian laboratories are not routinely practicing separation of serum from clot within two hours. Therefore, it becomes necessity to perform sample stability study at local laboratory set up.

In this study, we found that our all analytes except sodium, creatinine, urea, albumin and ALT shows statistical significant difference when comparing 0.5 hour sample with primary collection and secondary collection tube stored at 2 to $8^{\circ} \mathrm{C}$ for 24 and 48 hours, our result differ from previous studies. This might be due to a range of studies applied different test for comparing sample stability study e.g. repeated measure ANOVA, ${ }^{14}$ One way ANOVA, ${ }^{15}$ Friedman test ${ }^{16}$ and paired sample Student's ttest. As we want to find out difference between 0.5 hours to 24 hours and 0.5 hour to 48 hours sample we had applied paired sample Student's ttest also verified with repeated measure ANNOVA.

As we found that in our set up even after separation of serum from clot within 2 hours and stored at 2 to $8^{\circ} \mathrm{C}$ for 24 hours had statistical significant difference, therefore we applied concept of significant change limit (SCL) ${ }^{17}$ which says even if statistical significant differences exist how much analytical system contributes to this difference.

In this study, we found that serum sodium decreases when serum-clot is not separated and increases when serum is separated and stored as long as 48 hours. But these differences are within SCL. Thus, our observation for serum sodium was consistent with similar studies investigating serum with prolonged contact with cells. 7,9,12

All studies observed that serum potassium drastically increases if serum is not separated from clot within 2 hours and the rises in values is more due to hemolysis even when sample is stored at 2 to $8^{\circ} \mathrm{C}$. We also found that serum potassium is very high and out of SCL even at 24 hours storage results ${ }^{18-20}$ After 24 hours potassium increases because diffusion of potassium from intracellular to extracellular as a consequence of failure of Na-K ATPase pump in erythrocyte due to very low extracellular glucose. ${ }^{21}$

Ionized calcium is decreased and it is more pronounced in the serum sample without clot. Ionized calcium is out of significant change limit. Serum chloride level remains stable in both with or without serum-clot separation sample. ${ }^{7,8,22}$

Glucose concentrations decreases with increasing serum-clot contact time in plain tube. Concentration of glucose at 48 hours is lower in compare to 24 hours and 0.5 hours, it also shows a statistical significant difference. This decrease in concentration was attributed to glycolytic action of erythrocytes and leukocytes. ${ }^{23,24}$ However, we stored both tube at 2 to $8^{\circ} \mathrm{C}$ which will minimize the rate of decreases in glucose concentration.

We have not observed difference in concentration of creatinine, urea, uric acid, total bilirubin, total protein and albumin, it suggests that these parameters are stable in both with or without serum-clot separation tube if they are stored at 2-8 ${ }^{\circ} \mathrm{C} .{ }^{8}$ But Heinz et al reported creatinine increased by $60 \%$ in serum after $24 \mathrm{~h}$, which was probably attributable to interference of pseudo-creatinines with the kinetic Jaffe reaction. ${ }^{22}$

Cholesterol showed upward trend, the change in concentration is more pronounced in primary tube than serum-clot separating tube. A similar trend was also noted in serum specimens, the mechanism proposed was that cholesterol was being continuously removed from blood cells via lecithin:cholesterol acyl transferase. ${ }^{22}$ Triglyceride was stable over the 56-hours period in other studies but in this study, we observed upward trend in triglyceride and HDLcholesterol shows downward trend but both were within significant change limit. ${ }^{22}$ In contrast to Ono et al, ${ }^{9}$ Murphy et $\mathrm{at}^{25}$ and Dern et $\mathrm{al}^{26}$ our study shows AST, ALT and ALP within significant change limit. ${ }^{9,25,26}$ In this study, AST activity changed only a few units despite the marked percentage biases and may not be considered as clinically significant as long as 48 hours of storage in all four groups. Heins et al. also noted the stability of AST stayed until one week at room temperature. ${ }^{22}$ Bobby $\mathrm{L}$ et al observed that ALT was stable up to 40 hours, then it lost $20 \%$ of activity at 48 and 56 hours (14). Our result for AST and ALP is similar to other studies. ${ }^{7,9,12}$ 


\section{Conclusion}

In conclusion, only a few routine analytes e.g. serum potassium, ionized calcium and plasma glucose required stringent control before serum-clot separation. Most routine tests can tolerate fairly long delays in transportation without changes in analyte concentration. And when considering analytical variation result can be given as long as 48 hours even without serum-clot separation. However, our intent in reporting this study is in no way to encourage deviation from the standard practice of separating the serum from the clot as soon as it is practicable to do so. Rather, we hope that the results we have presented will help assess which of the constituents may be assayed in blood stored for prolonged times under commonly encountered storage conditions, when such prolonged storage occurs inadvertently or is unavoidable.

\section{References}

1. Kaplan LA: Determination and application of desirable analytical performance goals: the ISO/TC 212 approach. Scand J Clin Lab Invest 1999;59:479-82.

2. Lippi G, Chance JJ, Church S, Dazzi P, Fontana $\mathrm{R}$, Giavarina D, et al. Preanalytical quality improvement: from dream to reality. Clin Chem Lab Med 2011;49:1113-26.

3. Lippi G, Guidi GC, Mattiuzzi C, Plebani M. Preanalytical variability: the dark side of the moon in laboratory testing. Clin Chem Lab Med 2006;44:358-65.

4. Lippi G, Simundic AM. Total quality in laboratory diagnostics. It's time to think outside the box. Biochem Med 2010;20:5-8.

5. Lippi G, Plebani M, Simundic AM. Quality in laboratory diagnostics: from theory to practice. Biochem Med 2010;20:126-30.

6. Lippi G, Simundic AM, Mattiuzzi C. Overview on patient safety in healthcare and laboratory diagnostics. Biochem Med 2010;20:131-43.

7. Chu SY, MacLeod J. Effect of three-day clot contact on results of common biochemical tests with serum. Clin Chem. 1986;32:2100.

8. Rehak NN, Chiang BT. Storage of whole blood: effect of temperature on the measured concentration of analytes in serum. Clin Chem. 1988;34:2111-4.

9. Ono T, Kitabuchi K, Takehara M, Shiiba M, Hayami K. Serum-constituents analyses: effect of duration and temperature of storage of clotted blood. Clin Chem. 1981;27:35-8.

10. Oliver TK, Young GA, Bates GD, Adamo JS. Factitial hyperkalemia due to icing before analysis. Pediatrics. 1966;38:900-902.

11. Larsson L, Ohman S. Effect of silicone-separator tubes and storage time on ionized calcium in serum. Clin Chem. 1985;31:169-70.

12. Zhang DJ, Elswick RK, Miller WG, Bailey JL. Effect of serum-clot contact time on clinical chemistry laboratory results. Clin

Chem.1998;44:1325-33.

13. Young DS, Bermes EW. Specimen collectionand processing; sources of biological variation. In: Tieta NW, ed.Textbook of clinical chemistry, Philadelphia:WB Saunders Co.,1986:478-518.

14. Bobby L. Boyanton, Jr., and Kenneth E. Blick. Stability Studies of Twenty-Four Analytes in Human Plasma and Serum Clinical Chemistry 48, No. 12,2002

15. Nadja N. Rehak and Betty T. Chlang Storage of Whole Blood: Effect of Temperature on the Measured Concentration of Analytes in Serum. Clinical Chemistry, Vol. 34, No. 4, 1988.

16. Serap Cuhadar, Ayşenur Atay, Mehmet Koseoglu, Ahmet Dirican, Aysel Hur 1 Stability studies of common biochemical analytes in serum separator tubes with or without gel barrier subjected to various storage conditions Biochemia Medica 2012;22(2):202-14.

17. Passey RB. Quality control for the clinical chemistry laboratory. In: Kaplan LA, Pesce JA, eds. Clinical chemistry: theory, analysis, and correlation, 3rd ed. St. Louis: CV Mosby Company, 1996:385-91.

18. GoodmanJR. Vincent $J$, Rosen I. Serum potassium changesin bloodclots. Am J Clin Pathol 1954;24:111-3.

19. Webster, JH, Neff J, Sciafilno SS, Richmond AM Evaluation of serum potassium levels.Am J Clin Pathol 952;22:833-42.

20. DanowskiI'S. The transfer of potassium across the human blood cell membrane.J Biol Chem 1941 139:693-705

21. Jandl JH. Blood: a textbook of hematology. Physiology of red cells, 2nd ed. Boston: Little Brown and Company, 1996:157-77.

22. Heins M, Heil W, With old W. Storage of serum or whole blood samples? Effects of time and temperature on 22 serum analytes. Eur J Clin Chem Biochem 1995;33:231-8.

23. Chan AYW, Swaminathan R, Cockram CS. Effectiveness of sodium fluoride as a preservative of glucose in blood. Clin Chem 1989;35:315-7.

24. Weisman M, Klein B. Evaluation of glucose determination in untreated serum samples. Clin Chem 1986;32:1544-8.

25. Murphy, J. R., The influence of $\mathrm{pH}$ and temperature (In some physical properties of normal erythrocytes and erythrocytes from a patient with hereditary spherocytosis. J. Lab. ('tin. Med. 69, 758 (1967).

26. Dern, R. J., Brewer, G. J., and Wiorkowski, J. .1., Studies on the preservation of human blood. II. The relationships of erythrocyteadenosine triphosphate levels and other in vitro measures to red cell storageahility. J. Lab. C/in. Med. 69, 968 (1967). 